\title{
TONE SHIFT AND SPREAD IN TAITA I*
}

\author{
David Odden \\ Ohio State University
}

\begin{abstract}
Numerous Bantu languages have processes of rightward shift or spread of $\mathrm{H}$ tone. Sometimes the process is quite simple: every $\mathrm{H}$ shifts once to the right (as in Cijita) or spreads once to the right (as in Kikerewe). The tonal system of Taita is more complex in that both shifting and spreading are found in the language. Furthermore, the extent of tone shift or spread is not just one syllable; sometimes, $\mathrm{H}$ tone can shift or spread by two syllables. An analysis of the tonal system of the Dembwa dialect of Taita is given here. It is argued that the facts of the language are best described in terms of two rules of rightward spreading and a third rule of tone delinking. The argument for analyzing the tone system in terms of three interacting rules rather than one unified rightward movement process resides in the fact that the environments for the three processes only overlap partially. On the theoretical front, these results support a general decomposition of the process of tone shift into tone spread interacting with tonal delinking, rather than including the operation of shift in the formal repertoire of primitive phonological operations.
\end{abstract}

\section{Introduction}

The goal of this paper is to describe tone in the Dembwa dialect of the Bantu language Taita (Dabida), which is spoken in south central Kenya. A future paper will analyze the Mbololo dialect. The core problem of Taita tonology is summed up

\footnotetext{
* Data for this paper was collected in Nairobi during April-May 1997 from Godrick Mughosi, whom I thank for providing these data, and was supported financially by NSF Grant SBR9421362. I also thank the Department of African Languages and Linguistics at the University of Nairobi, especially Nyombe Bureng and Mohamed Abdulaziz, for making this research physically possible. Earlier versions of this paper were presented at ACAL 30 at the University of Illinois, and at Ohio State University and the University of Troms $\varnothing$; I would like to thank those audiences for their valuable comments. In this paper, $<$ bh $>$ represents [b] (except after [m]), $<$ b' $>$ represents [6] (which does not occur after [m]), <d $>$ represents [d] except after [n] where it represents [d], $<b>$ represents $[\beta]$ except after $[\mathrm{m}]$ where it represents $[\mathrm{b}],\langle\mathrm{g}\rangle$ represents $[\gamma]$ except after $\langle\mathrm{n}\rangle$ ([घ]) where it represents [g], <g'> represents [g], and $<$ ng' $>$ represents [ $\mathrm{g}]$. The phonemes $\langle\mathrm{bh}>$, $\left\langle\mathrm{b}^{\prime}\right\rangle$ and $\langle$ g' $>$ are marginal in this dialect of Taita. Vowels are predictably lengthened in the penultimate syllable of the phrase; despite this predictability, length will be included in the transcriptions because it is phonologically relevant.
} 
in (1). The nouns baandu and baaka appear to be tonally identical, judging from their citation forms, but when an adjective follows either noun, tonal differences emerge. After baandu the adjective balaacha has no $\mathrm{H}$ tone, but after baaka the penultimate syllable of the same adjective takes a level $\mathrm{H}$ tone. A similar difference is seen when these nouns appear after the (imperative) verb taala, which has no $\mathrm{H}$ tone in its citation form. The verb has a final $\mathrm{H}$ and the following noun has an initial falling tone when the noun is baandu, but, before baaka, the same verb lacks any $\mathrm{H}$ and baaka itself has a level $\mathrm{H}$ tone. The explanation for these differences lies in the fact that the nouns themselves have tonally different underlying representations, /ba-ndu/ versus /ba-ká/. The appearance of $\mathrm{H}$ tone after the verb taala is due to the fact that there is an underlying $\mathrm{H}$ on the verb /talá/.
(1) baa-ndu
'people'
baa-ka
'women'
ba-ndu ba-laacha
'tall people'
ba-ka ba-láácha
'tall women'
taala
'count!'
talá báa-ndu
'count people!'
tala báá-ka
'count women!'

The surface tonal opacity of these examples derives from two factors. First, $\mathrm{H}$ tone shifts rightwards by one or two syllables, so the surface location of a $\mathrm{H}$ is indirectly related to its underlying location. Second, final $\mathrm{H}$ is deleted, but such a surface-absent $\mathrm{H}$ still affects how tones spread into a word from the left, and underlying but surface-absent $\mathrm{H}$ also explains why some words which have no $\mathrm{H}$ tones in citation forms induce $\mathrm{H}$ on following words. The primary challenge in understanding Taita tonology is, then, that the recovery of underlying representations is not a simple matter of inspecting the surface form of simple words.

Taita tonology is reminiscent of Sukuma tonology [Richardson 1959, Goldsmith 1985, Sietsema 1989, Yukawa 1989, Batibo 1991, Roberts 1992] of western Tanzania, where $\mathrm{H}$ can shift rightward by two or more syllables, and deletes prepausally. Many Bantu languages in the region extending from south central Kenya to western Tanzania exhibit rightward spreading by one syllable (Kerewe [Odden 1998a] spoken in Lake Victoria) or more (Shambaa [Odden 1982], Mgonja Pare [Odden 1985] both of northern Tanzania), as well as shifting by one syllable found in Nyamwesi [Schadeberg \& Maganga 1992] of western Tanzania, Kikuyu [Clements \& Ford 1979] of south central Kenya, Ruri [Massamba 1982] and Jita [Downing 1990] of Lake Victoria, and especially Chaga [Nurse \& Phillipson 1977, McHugh 1990] of north central Tanzania, which is most closely related to Taita among those languages with documentation of the tonal system. Both shifting and spreading are found in Holoholo [Coupez 1955] of western Tanzania and eastern Congo. While rightward spread and shift of $\mathrm{H}$ are phonetically natural processes in human languages, tone shift and spreading, and especially processes of shift and spread by only one or two syllables, enjoy a frequency of occurrence in the Bantu languages of this area well in excess of that found in other areas of Bantu or outside of Bantu. It is interesting that Sukuma happens to be the Bantu language which is typologically most like Taita, since Sukuma is not particularly closely related to Taita within Bantu (being members of the West Tanzania and Taita- 
Chaga subgroups, respectively) and spoken at nearly the opposite end of this geographical continuum which favors tone shift.

The treatment of shift versus spread in Bantu has not been consistent in the tonal literature, nor is there uniformity in the analysis of shifting and spreading by two syllables. As far as the distinction between shift versus spread is concerned, one strategy is to treat these as separate operations, where shifting moves a tone from one syllable to another in one step. ${ }^{1}$ On the other hand, shifting could be decomposed into multiple steps of spreading and delinking. Batibo [1991] presents Sukuma tone shift as a direct shift operation, whereby /kubónela/ 'to see for' maps to kubonelá and /kubóna mahalage/ 'to see some beans' maps to kubona mahálage in one step. Schadeberg [1991] treats Nyamwesi tone shift as involving direct movement of tone from one vowel to another, and Sietsema [1989] provides a one-step treatment of rightward shift in Ciruri. In the analysis of Kang [1997], the mapping from /kubóna mahalage/ maps to kubona mahálage in one step, but this is due to the author's particular theoretical approach, Optimality Theory, in which the entire mapping from underlying to surface forms take place in one step. In contrast, Downing [1990] treats Jita tone shift as the effect of a rule of Rightward Spread followed by Leftward Delinking of a multiply linked tone. Authors may offer both types of analysis-for example, Kenstowicz \& Kisseberth [1988] posit an unbounded rule of direct tone shifting, but also note that the process might be decomposed into spreading followed by delinking. Sietsema [1989] presents a one-step account of tone shift (by one syllable) in Ciruri, but a two-step spread and delink account for Sukuma. Downing [1990] posits a twostep treatment of righward shift by one syllable, but a single rule Reassociation to Accent which shifts $\mathrm{H}$ directly to the final syllable when two object prefixes are present.

There is even less uniformity of precedent in the treatment of shift or spread by two syllables in Bantu, largely because such processes are quite uncommon. The reason why the treatment of such a process might be of theoretical importance is that two-syllable shift is generally held to violate theoretical strictures such as locality conditions on rules. A rule such as (2), which could be employed in describing Sukuma, would require the explicit inclusion of an intermediate vowel which is skipped over.

\footnotetext{
1 A further analytic variable which has come into play in the analysis of tone spread and shift is "accent", construed either as some variety of metrical structure or as an autosegmental diacritic marker which controls initial associations. The latter concept of "accent" enjoyed popularity in the initial development of autosegmental phonology beginning with Goldsmith [1976]. Beginning with Pulleyblank [1983], "accent" was later theoretically reinterpreted as being a strong position in a metrical grid. Accordingly, some analyses of $\mathrm{H}$ shift involve $\mathrm{H}$ tones being directly attracted to accented positions (Nguni, in the analysis of Peterson [1989]), and others involve spreading $\mathrm{H}$ up to an accented position (Sukuma, in the analysis of Sietsema [1989], Kang [1997]). Idsardi \& Purnell [1995] take this progression to its logical end, claiming that Sukuma "tone" is purely metrical structure, not tone.
} 
(2)

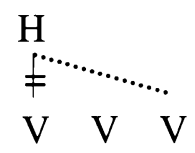

As observed by Kang [1997: 55], "It is a sacred tenet of current phonological theories that phonological processes observe a strict locality condition." This consideration has inspired a considerable number of responses. Goldsmith [1985] solves the problem in an autosegmental accent account by "precompiling" part of tone shift by selecting an underlying tone melody $\mathrm{LH}$ (not just $\mathrm{H}$ ) which associates to accented syllables, combined with a rule which directly shifts $\mathrm{H}$ once to the right. In other words, apparent shift by two syllables is decomposed into a special feature of underlying forms plus one tone shift rule. Roberts [1992] posits three separate tone spreading rules, each spreading tone once to the right. Sietsema [1989], in contrast, posits metrical structure which, given certain assumptions allows spreading by two or three syllables, without violating any locality conditions.

This paper will present data from Taita which may be useful in resolving some of these controversies. One of the reasons why previous treatments of spread versus shift and especially double shift have been inconclusive is that the languages studied do not provide evidence to choose between competing analyses, so adjudication of analytical disputes is left to theoretical assumptions which themselves are in dispute. It will be argued here that the best analysis of Taita tone is one which admits two separate rules spreading tone by one syllable to the right, and a separate delinking rule. The crux of the argument for treating Taita tonology with these separate rules, rather than one rule, is simply that the rules do not have the exact same conditions (in contrast to, for example, Jita, where the forms which undergo Downing's rule Rightward Spread are exactly the forms that undergo Leftward Delinking, and therefore no fact of Jita compels a two-step treatment of shift rather than a one-step treatment), and especially that it is possible to find a context where one can observe the effect of tone spreading, free of the effects of tone delinking, which argues for the independence of these two processes.

\section{Verbal Tone}

We begin by looking at alternations in the verb, which reveal most of the essentials of the Dembwa tone system. As in most Bantu languages, Dembwa verb stems fall into two classes, one having no $\mathrm{H}$ tone, the other having an underlying $\mathrm{H}$ tone on the first syllable of the stem. The actual surface realization of the underlying $\mathrm{H}$ varies as a function of the number of syllables in the stem. The realization of a $\mathrm{H}$ verb, as a function of the number of syllables in the stem, is summarized in (3), with two tones for the penult because that vowel is long and has two tone bearing units. 
(3) 1 syllable: $\mathrm{L}$

2 syllables: $\quad-\mathrm{HH}-\mathrm{H}$

3 syllables: $\quad \mathrm{H}-\mathrm{HL}-\mathrm{L}$

4 syllables: $\quad \mathrm{L}-\mathrm{H}-\mathrm{LL}-\mathrm{L}$

5 syllables: $\quad$ L - H - L - LL - L

If the stem contains only a single syllable, as in (4), the underlying $\mathrm{H}$ simply does not surface (in citation forms). The underlying $\mathrm{H}$ in monosyllabic $\mathrm{H}$ roots can be recovered by adding a suffix, thereby making the stem longer than monosyllabic. The examples in (4a) represent stems lacking $\mathrm{H}$ tone, those in (4b) $\mathrm{H}$ toned stems.

(4)
a. kuu-gw-a 'to fall'
(cf. ku-gw-ii-a
'to fall for')
kuu-sh-a 'to grind'
(cf. ku-sh-aan-a
'to grind each other')

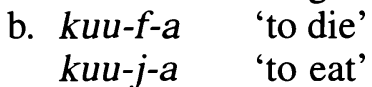
(cf. $k u-f-$-í-á
'to die on')
(cf. ku-j-áán-á
'to eat each other')

The roots in the second group would be expected to have a surface final $\mathrm{H}$ since they have an underlying $\mathrm{H}$. The surface lack of $\mathrm{H}$ in the bare form of those verbs is due to a general rule (5) which deletes final single $\mathrm{H}$ tones. This rule explains why phrase-final $\mathrm{H}$ is phonetically lacking in the language except when the penult is also $\mathrm{H}$ toned (a phrase boundary is notated here as \#\#). This deletion of final $\mathrm{H}$ tones is ubiquitous, and will be abundantly documented in the discussion of nouns in section 4 .

\section{(5) Final H Deletion}

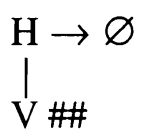

Disyllabic $\mathrm{H}$ toned verbs have the surface tone pattern $\mathrm{HH}-\mathrm{H}$, as shown in (6). This is the result of a rightward spreading rule (7), which turns underlying final $\mathrm{H}$ $\mathrm{L}$ into $\mathrm{HH}-\mathrm{H}$.
(6) ku-bóón-á 'to see' ku-láál-á 'to sleep'
ku-táál-á 'to count'
ku-óóm-á 'to be dry'
ku-lúúm-á 'to bite'
ku-déék-á 'to cook'

(7) Spreading

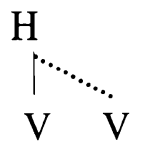


Questions may arise as to the formal analysis of the tone system but will not be considered in depth because the facts of the language and. especially, the theoretical tools at our disposal often fail to converge at a unique formal account. While focusing on the fine-grained details of a formal account will be eschewed, certain quasi-theoretical questions naturally arise and will be mentioned as appropriate. One such question regards the exact mode of tone spreading. The underlying form of [ku-bóón-á] is /ku-bón-a/. The shortness of the penult is motivated by two facts; first, vowel length appears predictably — and only —on the phrasal penult, and second, the length of the vowel [oo] alternates depending on position, hence kubón-áan-a 'to see each other', ku-bon-á báandu 'to see people'. The underlying tone of the final inflectional suffix is demonstrated by the fact that it bears $\mathrm{H}$ only in a highly restricted set of contexts - cf. kubón-áan-a and ku-liima-a 'to culti-vate', the latter being a verb stem which has no $\mathrm{H}$ tones. In the surface form kubóóná, we end up with three $\mathrm{H}$ toned moras on the surface, starting with one. How can this be explained?

One explanation is that the penultimate vowel has already become long by the time Spreading applies. In that case, Spreading may be stated as operating from syllable to syllable, resulting in spread of $\mathrm{H}$ to as many moras as are required to get continuous association between the source and target syllables. Thus, (7) iterates throughout the syllable which initially contains the $\mathrm{H}$, until the next syllable is reached. Another way to get the requisite output is to order Spreading before lengthening of the phrase-penult vowel. Thus, the output of Spreading would be kubóná. When an additional mora is added to the penult (assuming that the added mora is at the right edge of the syllable), that mora bears $\mathrm{H}$ tone, since otherwise a universally disallowed "gapped" configuration would result, that is, a $\mathrm{H}$ linked to a discontinuous sequence of TBU's. There being no compelling theoretical or factual basis for preferring one of these accounts over the other, we leave the matter open.

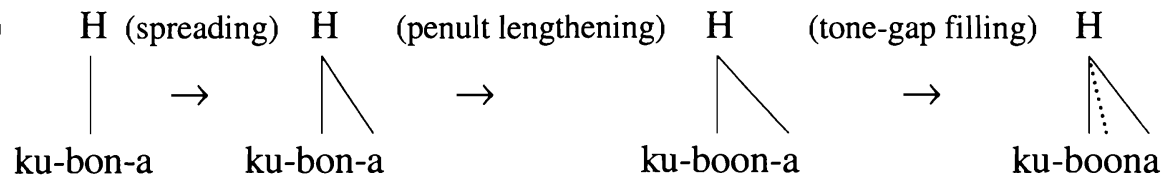

If the verb stem is trisyllabic, as in (9), the stem initial $\mathrm{H}$ spreads to the following syllable, where it appears as a falling tone.

(9)
ku-dáfúun-a 'to chew'
ku-tésíi-a 'to help'
ku-bón-áan-a 'to see each other'
ku-síkíir-a 'to hear'

This surface pattern is the result of the same rightward spreading found in disyllabic stems. The data reveal that the spreading is bounded- $\mathrm{H}$ does not spread to the end of the word-and, furthermore, when $\mathrm{H}$ spreads to a penult, it is realized as a falling tone. The penult falling tone can be explained in various ways. As discussed in Kisseberth \& Odden [to appear], many Bantu languages exhibit 
tonal phenomena within the last two syllables of the phrase pertaining to lowering of pitch, such as the fact that prepausal tones may be automatically realized as falling tones (e.g. Kimatuumbi [Odden 1996]), that final Hs shift to the left (e.g., Runyankore [Poletto 1998]), and especially that penultimate syllables tend to be phonetically falling-toned rather than level in languages which do not otherwise have falling tones (e.g., Yao [Odden 1998b], Runyankore). Numerous formal explanations for this pattern in the synchronic phonology can be proposed, and the one which will be adopted here is that a L tone-a so-called boundary tone-is introduced in phrase-final position and associates with the last two syllables. The extragrammatical origin of the phenomena seems to be the well-known lowering of pitch at the end of the utterance found in numerous languages.

Dembwa is like Yao and Runyankore, where, as a first approximation, one might simply say "penult $\mathrm{H}$ tones are phonetically pronounced with falling pitch before final L tones". But like the situation in Yao and Runyankore, this statement is not surface true, and in Dembwa we find forms such as nadáája 'I just ate', with a level penult $\mathrm{H}$ before a final surface $\mathrm{L}$. Thus, the realization of penult $\mathrm{H}$ as a fall is not due to simple phonetic interpretation. It is, however, entirely explicable: in nadáája, the final syllable also has an underlying $\mathrm{H}$, as will be discussed later.

Whether or not this falling tone should be formally represented as (10a) or (10b) is largely a theoretical matter, hinging on the status of surface underspecification. It is controversial whether non-H TBU's in Bantu languages are phonologically specified as L or simply lack tone where their lower pitch is assigned by a rule of phonetic implementation. The only context in Dembwa where $\mathrm{L}$ tone would have phonological utility is precisely in the penult, as a means of identifying a falling tone as distinct from a level $\mathrm{H}$. It will be shown that this distinction is important in the phonology, because the fall/level $\mathrm{H}$ distinction allows us to understand the conditions for tone spread versus shift. The representation $(10 \mathrm{~b})$ will therefore be assumed for the penult fall; a boundary L spreads from a prepausal syllable (the boundary L tone only associates to an unoccupied syllable), overriding the linkage of the $\mathrm{H}$ to the second mora of the syllable. Representation (10b) provides a "positive" means of referring to falling tones, whereas (10a) allows falling tone to be referred to only by dint of referring to lack of association, and a desideratum in phonological theory has been to eliminate explicit references to the lack of entities.
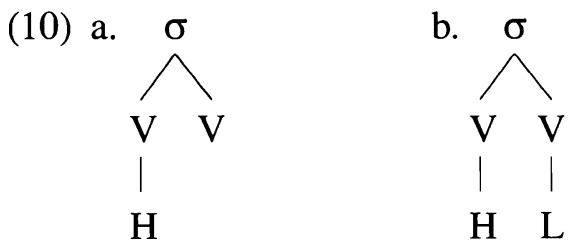

Assuming that Spreading extends the lexical $\mathrm{H}$ to the penult, the phrasal $\mathrm{L}$ is assigned to the unoccupied final syllable. No more than one tone can appear on a single mora in the language, hence contour tones only appear on the penult, which 
is the only bimoraic syllable. In kubóóná, the final syllable has a $\mathrm{H}$, which prevents the phrasal L from associating; thus, we do not get *[kubóónâ]. In kubónáana, the final syllable can receive the phrasal $L$ since it has no other tone. That $L$ then spreads leftward to the penult and any association between the penult $\mathrm{H}$ and the second mora of the long vowel is eliminated. A derivation is given in (11).

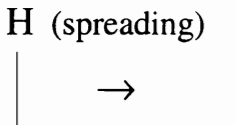

ku-bon-aan-a ku-bon-aan-a

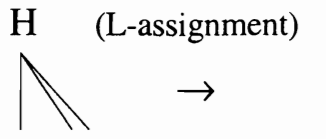

ku-bon-aan-a

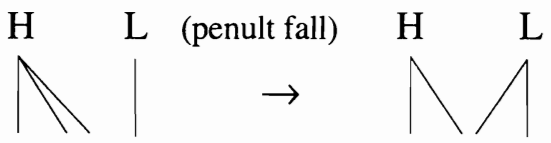

ku-bon-aan-a

Spreading of the final $L$ to the penult is the result of the following rule.

\section{(12) Penult Fall}

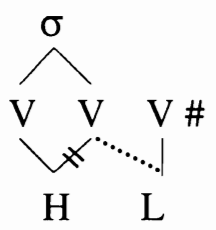

When the stem has four syllables or more, a rather different realization of the $\mathrm{H}$ is found. In that case, the $\mathrm{H}$ shifts to the following syllable, shown in (13).

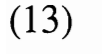
ku-dek-í-aan-a
ku-duk-í-aan-a
ku-sikír-aan-a
ku-chemúsh-ii-a
ku-chemúsh-i-aan-a

'to cook for each other'

'to carry for each other'

'to hear each other'

'to boil for'

'to boil for each other'

The pattern for stems having four or more syllables might seem to be markedly different from that of shorter stems, where the $\mathrm{H}$ remains on its original syllable, but here the stem initial syllable has no surface $H$. The pattern of longer stems involves just one further complication compared to the previously motivated pattern of spreading seen in shorter verbs, namely delinking of the $\mathrm{H}$ from its original position. The difference between the shifting pattern of longer verbs and the spreading pattern of shorter verbs can be understood in terms of the contexts where strings of adjacent $\mathrm{H}$ tones occur on the surface in the language. Strings of Hs, analyzed as a single $\mathrm{H}$ autosegment associated to multiple vowels, have a restricted distribution in the language, and are only found in three positions. The first context, spelled out in (14a), arises especially at the phrasal level in examples like tala sáb'úuni 'count soap!', where a sequence of $\mathrm{H}$ tones is preceded by a downstepped $\mathrm{H}$. It will be assumed here that surface downsteps are due to a process of phonetic implementation, whereby the second of two adjacent $\mathrm{H}$ tone autosegments is produced with lower pitch (see [Odden 1982]). Thus, in representation 
(14a), the second $\mathrm{H}$ tone is pronounced at a lower pitch and is conventionally transcribed with a raised exclamation marker to notate that pitch lowering. The second context where multiply-linked $\mathrm{H}$ is found is when the $\mathrm{Hs}$ are on the last two syllables of the utterance, as we have seen in disyllabic $\mathrm{H}$ verbs such as kutáalá. The third is when the $\mathrm{H}$ is on both the antepenult and the penult syllables, and on the penult specifically as a falling tone, as in kudáfúuna.

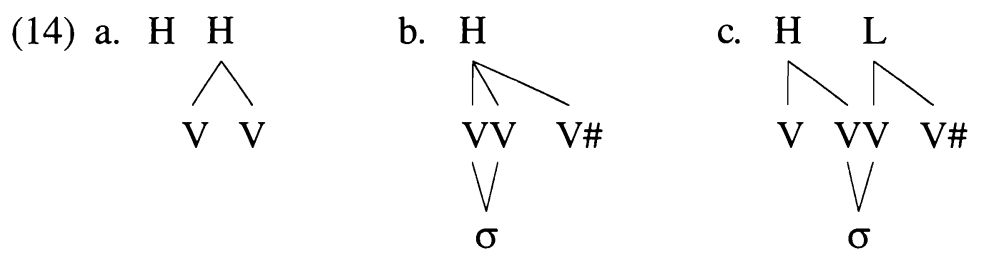

These are the only contexts where double-H sequences are found. Otherwise, whenever a string of Hs would be created by spreading over a number of syllables, the $\mathrm{H}$ delinks on the left, resulting in a surface pattern of tone shifting rather than tone spreading. This does not mean that a rule with such a condition is part of a formal grammar - this is a strictly descriptive statement. Deeper investigation of the proper mechanism for stating the conditions on Delinking would take us too far afield and would ultimately prove inconclusive.

\section{Delinking}

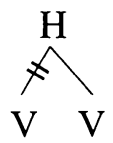

(except in contexts (14a-c))

Given Spreading, the first two syllables of a four syllable $\mathrm{H}$ verb such as found in (13) should be $\mathrm{H}$ toned. But in that context, the second $\mathrm{H}$ is not part of a falling tone on the penult (case (14c)) and the left branch of the $\mathrm{H}$ is not part of a falling tone (case (14b)), so nothing blocks delinking of the left branch of the lexical $\mathrm{H}$. Thus, the apparent shift of $\mathrm{H}$ to the right can be decomposed into independent processes of rightward spreading and delinking with partially overlapping environments.

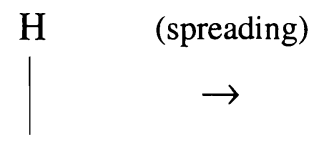

$\mathrm{k} \mathrm{u} \mathrm{d} \mathrm{e} \mathrm{ki} \mathrm{a} \mathrm{n} \mathrm{a}$

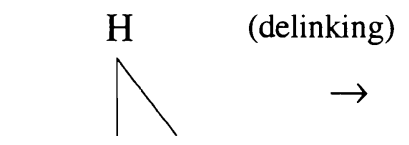

$\mathrm{k} \mathrm{u} \mathrm{de} \mathrm{k} \mathrm{i} \mathrm{aa} \mathrm{n} \mathrm{a}$ k u d e k i aa n a

These tonal processes operate throughout the language, and we now illustrate them further with one inflected tense. This will not only provide further examples of spreading and shifting of $\mathrm{H}$ tone, but will also show that there is a second spreading process which spreads $\mathrm{H}$ by an additional syllable, across the stem-prefix juncture and other contexts. The subject prefix na- in the immediate past tense is 
underlyingly $\mathrm{H}$ toned, and when the verb stem (-gw-a "fall", -sh-a "grind") lacks underlying $\mathrm{H}$ and is monosyllabic, the prefixal $\mathrm{H}$ spreads to the right where it is realized on the tense prefix -da- as a falling tone.

The derivation of these forms is the same as that given for trisyllabic $\mathrm{H}$ toned stems in the infinitive such as ku-dáfúuna. The $\mathrm{H}$ of the subject prefix spreads to the right and a boundary $\mathrm{L}$ is assigned to the final vowel. The boundary $\mathrm{L}$ spreads to the penult by virtue of the rule in (12) so that syllable has a falling tone. Since the antepenult $\mathrm{H}$ is immediately before a falling tone, the antepenult linkage of the $\mathrm{H}$ is retained and, consequently, the surface result is spreading and not shifting of the prefix $H$.

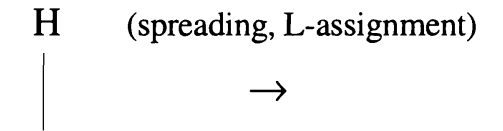

na-daa-gwa

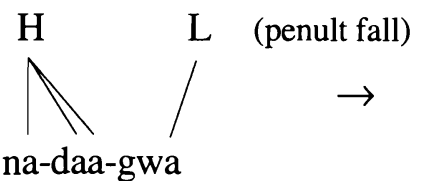

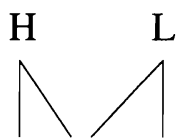

na-daa-gwa

In contrast, when the verb has a monosyllabic $H$ toned stem $(-j-a$ 'eat', $-n y w-a$ 'drink'), the prefixal $\mathrm{H}$ appears as a level $\mathrm{H}$ on the penult, as in (19). This too is the result of spreading the prefixal $\mathrm{H}$ to the penult. However, in this case, the $\mathrm{H}$ is not realized as a falling tone, since it is followed by the underlying root $\mathrm{H}$. Because of the underlying final $\mathrm{H}$, the boundary $\mathrm{L}$ cannot be associated (we therefore cannot tell if it is inserted and remains unassociated or is not inserted at all), so there is no falling tone-this despite the fact that the stem $\mathrm{H}$ which prevents linking the boundary $\mathrm{L}$ is eventually deleted by Final $\mathrm{H}$ Deletion (5). The consequence of the penult level $\mathrm{H}$ is that the leftmost branch of the $\mathrm{H}$ is not in one of the "protected" contexts of (14), so the $\mathrm{H}$ delinks from the subject prefix in the antepenult, as shown in (20).

na-dáá-ja 'I just ate'

na-dáá-nywa

'I just drank'

(20)

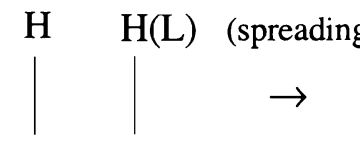

na-daa-ja
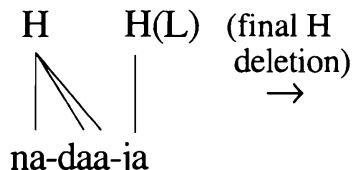

na-daa-ja

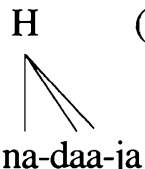

(L) (delinking)

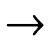

na-daa-ja
$\mathrm{H}$

(L)

na-daa-ja

With polysyllabic $\mathrm{H}$ verbs, as in (21), the $\mathrm{H}$ spreads to the prefix -da-, and no further, since the following root initial syllable has a $\mathrm{H}$ tone. The prefixal $\mathrm{H}$ is separated from the $\mathrm{H}$ of the root by a downstep, since in Dembwa, when one $\mathrm{H}$ spreads to meet another, the two Hs are always separated by a downstep. 

(21) na-dá-'láálá 'I just slept'
na-dá-'táálá 'I just counted'
na-dá-'búúná 'I just saw'
na-dá-'b'óórá 'I just sang'
na-dá-'déégá 'I just trapped'
na-dá-'lúúmá 'I just bit'

Here, both Hs spread one syllable to the right. The second $\mathrm{H}$ simply spreads without delinking, since the linkage that might be affected by (15) is the one to the long penultimate syllable; additionally, the left branch of the second $\mathrm{H}$ is preceded by a $\mathrm{H}$, which is another context where delinking does not apply. In the case of the first $\mathrm{H}$, that $\mathrm{H}$ spreads from the subject prefix, then delinks, because the syllable that it is delinked from is not immune to delinking, per (14).

(22)

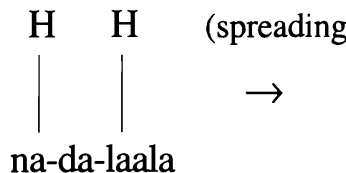

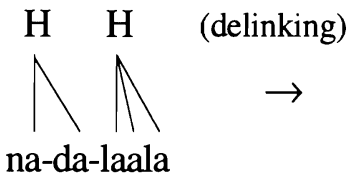

na-da-laala
$\mathrm{H} \mathrm{H}$

na-da-laala

Spreading of $\mathrm{H}$ two syllables to the right, not just one as in all previous examples, can be seen in (23) in data involving a disyllabic stem. Here we can see that the $\mathrm{H}$ of the prefix /ná/ spreads from the subject prefix to both the prefix -da- and the root initial syllable, which is the penult. The verb stem itself has no underlying $\mathrm{H}$.

$\begin{array}{ll}\text { (23) na-dá-líima } & \text { 'I just cultivated' } \\ \text { na-dá-líipa } & \text { 'I just paid' } \\ \text { na-dá-séeka } & \text { 'I just laughed' } \\ \text { na-dá-chíimba } & \text { 'I just dug' } \\ \text { na-dá-rúua } & \text { 'I just dug up' }\end{array}$

Spreading of $\mathrm{H}$ from /ná/ to da is expected given Spreading (7). Unlike previous examples, $\mathrm{H}$ spreads two syllables to the right, targeting the root initial syllable as well. Spreading by two syllables would result in intermediate nádáliima, and this is then subject to Delinking (15). That rule delinks prefixal $\mathrm{H}$ from the initial syllable na, but does not affect the linking between $\mathrm{H}$ and -da-, because the syllable immediately following -dá- has a falling tone.

(24)

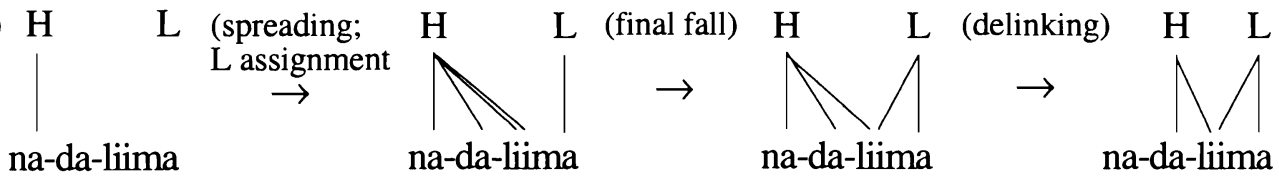

This pattern of double-spreading can be explained in terms of a second rule, ordered after Spreading (7), which spreads $\mathrm{H}$ by one more syllable. More data are needed to properly understand the context where this second spreading rule 
applies, in particular at the phrasal level, so we will anticipate the results of the next section, in order to allow discussion of the context for this spreading process. Note, in light of forms such as ku-dekíaana 'to cook for each other' or ku-dafúniaana 'to chew for each other' where $\mathrm{H}$ spreads only to the syllable immediately following the underlyingly $\mathrm{H}$ syllable, that Spreading (7) cannot be restated as unbounded spreading. Yet spreading processes in the language are not limited to just spread by one syllable. The rule which accomplishes spread to a second syllable on the right is formalized in (25).

\section{Cross-junctural Spreading}

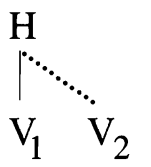

provided: V2 not final; the configuration must be brought about crucially by combination of a verbal prefix with a verb stem, or by concatenation of words.

This rule applies to the output of Spreading (7), and since (7) is more general(25) is essentially (7) with restrictions - anything which undergoes (25) necessarily has also undergone (7); thus, (25) results in double spreading/shifting. The distinction being drawn via the condition on (25) is that only a subset of forms containing a $\mathrm{H}$ followed by a toneless nonfinal vowel actually undergoes the rule, namely those where the requisite configuration is created by the concatenation of prefixes and stems, or words. Hence /ná-da-lima/ undergoes (7), becoming intermediate nádá-liima, then undergoes (25) to become nádálíima (eventually [nadálíima] by Delinking) because the target vowel ii comes to stand after a $\mathrm{H}$ toned vowel only by concatenation of the prefix $d a$ with the stem liima. Similarly (as discussed in section 3), /ku-dáfuna nyama/ undergoes (7) to become kudáfúna nyaama, and the $\mathrm{H}$ can spread again to give kudáfúná nyaama (ultimately [kudafuná nyaama] 'to chew meat'), because the conditions for (25) — a toneless non-final vowel —are present. Crucially, that condition is only satisfied because /kudáfuna/ and /nyama/ have been combined at the sentence level. Were these words not concatenated, the final vowel of the verb would fail the non-finality condition. In contrast, $/ \mathrm{ku}$ dáfuniana/, which surfaces as [kudafúniaana] 'to chew for each other', undergoes (7) to become kudáfúniaana, but the sequence [fúni] does not undergo (25), because the vowel $i$ is not put within the reach of $u$ by combination of prefix and stem, or word plus word. Similarly, in /kudáfuniana nyama/, even though the verb stands in phrase-medial position, the addition of the object nyaama is in no way relevant in determining the applicability of (25). In the intermediate form kudáfúniana nyaama (surface [kudafúniana nyaama] 'to chew meat for each other') the vowel which might undergo that rule is present and is nonfinal even without considering prefixes or other words, and therefore applicability of the rule in this case would not crucially involve the addition of a separate word.

The last examples of citation forms from verbs which we will consider involve a stem which is toneless and has more than two syllables. In such examples, the tone of the subject prefix shifts two syllables to the right, as in (26). 

(26) na-da-búduuka
'I just fell'
na-da-víviira
'I just smiled'
na-da-zígaana
na-da-rúgudiisha
'I just looked at'
'I just warmed up (fluids)'

These forms result from the same spreading mechanism which operates in the derivation of nadáliima, where $\mathrm{H}$ spreads two syllables to the right. Such spreading would result in the intermediate form ná-dá-búduuka, with a multiply-linked $\mathrm{H}$ tone. The two leftmost branches of that $\mathrm{H}$ are deleted. Considering the substring [nádá...], none of the factors which block delinking are present, so one application of delinking would give intermediate nadábúduuka. The conditions for delinking are still satisfied in this output, so delinking applies again this time to the substring [...dábú...], giving the surface form [nadabúduuka]. The net result is a rightward shift by two syllables, not just shift by one syllable and spreading by an additional syllable as was the case in [nadáliima]. The unity behind these forms is that the rightmost edge of the $\mathrm{H}$ extends two syllables to the right and the leftward edge of the $\mathrm{H}$ moves rightward at least once. The difference, then, lies in exactly how far to the right delinking operates.

Given that $\mathrm{H}$ can spread two syllables to the right, we must ask why in ná-dáasha from /ná-da-sha/ the prefixal $\mathrm{H}$ does not spread two syllables to the right, giving incorrect *nadááshá. The answer is that there is a positional asymmetry in the two spreading processes. The initial process spreading $\mathrm{H}$ one syllable to the right, rule (7), is insensitive to the positional properties of the target, and will spread $\mathrm{H}$ into a pre-pausal syllable as in kutáálá. The cross-junctural spreading process (25) which is responsible for the second spreading of $\mathrm{H}$, in contrast, never spreads $\mathrm{H}$ into a prepausal syllable.

\section{Phrasal Tone Spreading}

Phrasal combinations of verb plus noun are also subject to these rules of tone spreading and delinking. As seen in (27), if a monosyllabic $\mathrm{H}$ verb stem stands before a disyllabic noun, the $\mathrm{H}$ in the verb spreads once into the noun, where it results in a falling tone. Spreading (7) targets only one vowel, and since the second vowel of a disyllabic noun is pre-pausal and Cross-Junctural Spreading (25) does not target a prepausal syllable, no further spreading occurs. In these examples, Spreading (7) links the $\mathrm{H}$ to the initial syllable of the noun, and Cross-Junctural Spreading (25) spreads the $\mathrm{H}$ one syllable further to the right. Then, $\mathrm{H}$ delinks from the original syllable of the verb, because within the verb it does not precede a falling tone. No further delinking takes place, because the noun-initial $\mathrm{H}$ is followed by a falling tone. If the noun is trisyllabic, the $\mathrm{H}$ spreads twice, and delinks from the verb, as in (28). 
(27)

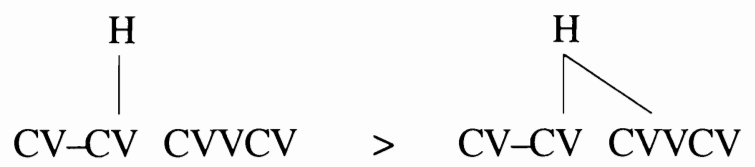

kuu-dwa 'to carry' (/ku-dwá/)

kuu-ja 'to eat' (/ku-já/)

nyaama 'meat' ku-dwá nyáama 'to carry meat'

muu-ndu 'person' ku-dwá múu-ndu 'to carry a person'

ndaaga 'knife' ku-dwá ndáaga 'to carry a knife'

maanga 'cassava' ku-já máanga 'to eat cassava'

mbooga 'vegetable' ku-já mbóoga 'to eat vegetable'

(28)

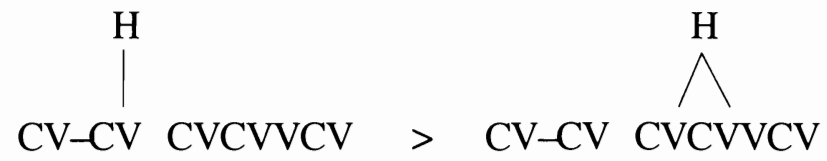

$\begin{array}{lll}\text { ma-baanu 'arrows' } & k u-d w a \text { má-báanu } & \text { 'to carry arrows' } \\ \text { mu-nyaango 'door' } & k u-d w a \text { mú-nyáango } & \text { 'to carry a door' } \\ \text { ma-geembe 'hoes' } & k u-d w a \text { má-géembe } & \text { 'to carry hoes' } \\ \text { ma-eembe 'mangoes' } & k u \text {-ja má-éembe } & \text { 'to eat mangoes' } \\ \text { ki-laambo 'thing' } & k u-j a \text { kíláambo } & \text { 'to eat a thing' } \\ \text { njogoolo 'rooster' } & k u-j a \text { njógóolo } & \text { 'to eat a rooster' }\end{array}$

The data in (29) show that with a disyllabic $\mathrm{H}$ toned verb, there is rightward spreading by one syllable inside the verb, and Cross-Junctural Spreading also applies between words to put a $\mathrm{H}$ on the first vowel of the noun, with the expected pattern of $\mathrm{H}$ delinking from the first syllable of the verb. In these data, the object is disyllabic, so only the initial linkage is lost, and the second syllable of the verb retains its $\mathrm{H}$ since it comes before a falling tone. However, if the following noun is trisyllabic or longer, as in (30), the only surface $\mathrm{H}$ appears on the initial syllable of the noun.

(29)

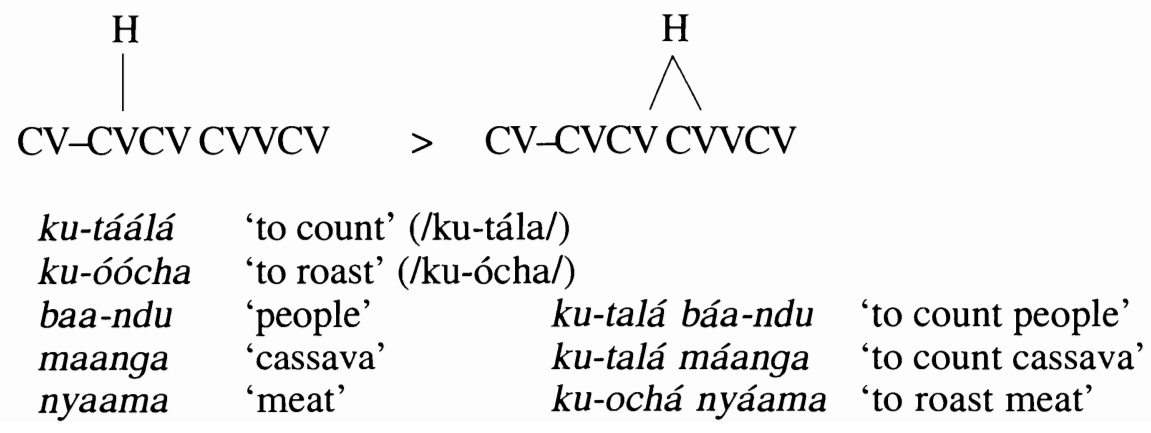


(30)

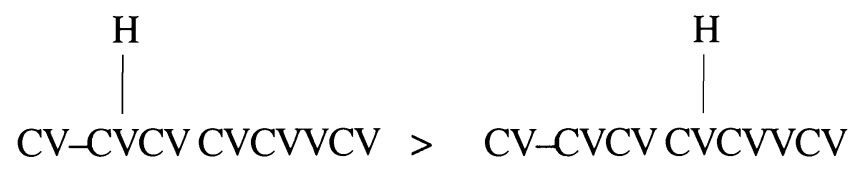

$\begin{array}{llll}\text { ma-baanu } & \text { 'knives' } & \text { ku-tala má-baanu } & \text { 'to count knives' } \\ \text { sufuriia } & \text { 'pans' } & k \text {-tala súfuriia } & \text { 'to count pans' } \\ \text { mu-sangaaga } & \text { 'sand' } & k u \text {-tala mú-sangaaga } & \text { 'to count sand' }\end{array}$

The total delinking of $\mathrm{H}$ from the verb is due to the fact that the final $\mathrm{H}$ in the verb, in intermediate kutalá fúfuriia, is followed by a level $\mathrm{H}$, thus delinking of the $\mathrm{H}$ affects both syllables in the verb.

If the verb stem is trisyllabic, as it is in (31), then the $\mathrm{H}$ cannot spread into the noun, since the two-syllable window for tone spreading occurs exclusively within the verb. Still, the presence of a following noun results in a significant change in the tone of the verb. Because there is a following noun, the final vowel of the verb which is targeted by Cross-Junctural Spreading is no longer in phrase-final position. The $\mathrm{H}$ can thus spread to the last syllable of the verb, on the grounds that it is not final (a determination which crucially involves the following word). Phrase medially, the $\mathrm{H}$ spreads twice then delinks twice, resulting in a surface shift of the tone by two syllables.

(31)

$\begin{array}{ll}\left.\right|_{\text {CV-CVCVCVCVVCV }} ^{H} & \text { CV-CVCVCVCVVCV } \\ \text { ku-dáfúuna } & \text { 'to chew" (/ku-dáfuna/) } \\ \text { ku-dafuná nyaama } & \text { 'to chew meat' } \\ \text { ku-chémúusha } & \text { 'to boil' (/ku-chémusha/) } \\ k u \text {-chemushá choofi } & \text { 'to boil beer' } \\ k u \text {-dék-îi-a } & \text { 'to cook for' (/ku-dék-i-a/) } \\ \text { ku-dekiá baa-ndu } & \text { 'to cook for people' }\end{array}$

Finally, when the verb is quadrisyllabic or longer, there are no cross-juncture effects: the verbal $\mathrm{H}$ spreads and delinks once.
$\mathrm{H}$
$\mathrm{H}$
CV-CVCVCVCV CVVCV
$>$ CV-CVCVCVCVCVVCV
ku-talíaana
ku-talíana baa-ndu
ku-dafúniia
ku-dafúnia maanga
'to count for each other' (/ku-táliana/)
'to count people for each other'
'to chew for' (/ku-dáfunia/)
'to chew cassava for' 
In comparing the data in (31) and (32), note should be taken of the fact that with trisyllabic verbs, $\mathrm{H}$ spreads twice in phrase-medial position, even though the $\mathrm{H}$ does not spread outside of the verb stem itself, whereas in longer verbs, in citation and phrase-medial contexts alike, spreading applies only once. This is because with longer verbs, the non-final status of the third stem vowel does not depend on the presence of a following word, and as discussed in the previous section, being in that kind of "derived environment" is one of the two conditions that has to be satisfied for Cross-Junctural Spreading to apply.

\section{Noun Tonology}

The remainder of the analysis concentrates on nouns, especially in phrasal contexts. Because Cross-Junctural Spreading occurs at the phrasal level, we will encounter a predominance of the pattern of spreading and shifting by two syllables.

Nouns in Bantu languages typically have more freedom in lexical tone contrasts, so while there are only two tonal categories of verbs irrespective of length, there are more underlying tonal contrasts in nouns. Deducing the underlying tone is harder in nouns, compared to verbs, because there are no morphological suffixation patterns that move underlying tones in and out of final position (where underlying tonal contrasts are opaque, due to Final $\mathrm{H}$ Deletion). Thus a major requirement for analysis of nominal tone is a clear means of identifying underlying tone. Fortunately, underlying tone can be deduced based on phrasal tone behavior. In citation forms, virtually all nouns fall into one of two classes: all-L, and nouns with final HH (there are a very few trisyllabic nouns like sáb'úuni 'soap', mlézéeni 'sp. of tree' with H-HL-L as their citation tone pattern, which derive from underlying HLL). The citation LL class must itself be further divided into a "neutral" class and a "H-inducing" class, a distinction not evident from the citation form alone. The underlying tone of a noun can easily be recovered by considering a phrase of the form "8 N's". Some citation LL nouns remain as such phrase-medially, having no effect on the following numeral "eight", as the data in (33) show.

$\begin{array}{lll}\mathrm{N} & \text { eight N } & \text { gloss } \\ \text { baandu } & \text { bandu bunyaanya } & \text { 'people' } \\ \text { meeda } & \text { meda bunyaanya } & \text { 'rivers' } \\ \text { mabiingu } & \text { mabingu bunyaanya } & \text { 'clouds' } \\ \text { mageembe } & \text { magembe bunyaanya } & \text { 'hoes' } \\ \text { mab' aata } & \text { mab'ata bunyaanya } & \text { 'ducks' } \\ \text { mageego } & \text { magego bunyaanya } & \text { 'teeth' } \\ \text { vikooto } & \text { vikoto bunyaanya } & \text { 'hands' } \\ \text { mbeeba } & \text { mbeba bunyaanya } & \text { 'rats' } \\ \text { ndaaga } & \text { ndaga bunyaanya } & \text { 'knives' } \\ \text { ng'oombe } & \text { ng'ombe bunyaanya } & \text { 'cows' } \\ \text { njogoolo } & \text { njogolo bunyaanya } & \text { 'roosters' }\end{array}$


Other nouns, which also have the final LL pattern in citation, do have a tonal effect on the following bunyaanya in that they induce the addition of a level $\mathrm{H}$ tone on the penultimate syllable of the numeral. It is assumed that these nouns have an underlying final $\mathrm{H}$.

$\begin{array}{lll}\mathrm{N} & \text { eight } \mathrm{N} & \text { gloss } \\ \text { bag'oosi } & \text { bag'osi bunyáánya } & \text { 'old men' } \\ \text { baaka } & \text { baka bunyáánya } & \text { 'women' } \\ \text { miidi } & \text { midi bunyáánya } & \text { 'trees' } \\ \text { milaamba } & \text { milamba bunyáánya } & \text { 'baobabs' } \\ \text { mikaate } & \text { mikate bunyáánya } & \text { 'breads' } \\ \text { vikaapu } & \text { vikapu bunyáánya } & \text { 'palm baskets' } \\ \text { virereende } & \text { virerende bunyáánya } & \text { 'shadows' } \\ \text { voongo } & \text { vongo bunyáánya } & \text { 'heads' } \\ \text { masooka } & \text { masoka bunyáánya } & \text { 'axes' } \\ \text { nyuumba } & \text { nyumba bunyáánya } & \text { 'houses' } \\ \text { mbuuba } & \text { mbuba bunyáánya } & \text { 'gardens' } \\ \text { ndaana } & \text { ndana bunyáánya } & \text { 'bows' } \\ \text { taago } & \text { tago bunyáánya } & \text { 'hens' } \\ \text { nyuungu } & \text { nyungu bunyáánya } & \text { 'pots' }\end{array}$

There is, from the point of view of the citation noun, an abstract contrast between nouns with no underlying $\mathrm{H}$, as in (33), versus nouns with final $\mathrm{H}$ that shifts from the noun to the following word, as in (34). The data from monosyllabic $\mathrm{H}$ verbs like $j a$ have shown that an underlying final $\mathrm{H}$ is deleted prepausally, but the final $\mathrm{H}$ can be detected at the phrasal level by the fact that it conditions appearance of $\mathrm{H}$ on a following word. Given the hypothesis that the nouns have underlying final $\mathrm{H}$ (hence the underlying forms for (34) are /ba-g'osĩ/, /ba-ká/, /milambá/ and so on), it is expected that this $\mathrm{H}$ should shift two syllables from the final syllable. The hypothesized final $\mathrm{H}$ then explains why $\mathrm{H}$ appears on the numeral, after select nouns. Further and more direct evidence will be considered later in this section to show that such nouns have word-final $\mathrm{H}$, because in some cases the $\mathrm{H}$ can be directly observed in its underlying position. Finally, the $\mathrm{H}$ on the penult of the number appears as a level $\mathrm{H}$, which can be explained by positing final $\mathrm{H}$ on /bunyanyá/: this $\mathrm{H}$ prevents penultimate falling tone, thus resulting in maximal delinking of the $\mathrm{H}$ after it has spread.

The third class of nouns are those with $\mathrm{HH}$ in their citation form, which changes to LH before bunyaanya, as in (35). These nouns underlyingly have a $\mathrm{H}$ on their penultimate syllable; thus, the underlying form of mizáátá is /mi-záta/, and this $\mathrm{H}$ undergoes Spreading. The process spreading $\mathrm{H}$ from the penult to the final syllable is the same as the one which operates in disyllabic infinitives such as kutáálá. In nouns as well, $\mathrm{H}$ spreads from the penult to the final syllable in the citation form. Since the left branch of the $\mathrm{H}$ is on a long vowel in the citation form mizáátá, it does not delink. However, when the noun is in phrase medial position, 
(35)

N
mizáátá
misééngé
misírdú
váálá
mafúúmú
matúúkú
kóóshí
chóóká
mbúúrí
ng'óóndí
ngáángá
tî́ndí
ngúúkú

eight $\mathrm{N}$

mizatá bunyaanya

misengé bunyaanya

misidú bunyaanya

valá bunyaanya

mafumú bunyaanya

matukú bunyaanya

koshí bunyaanya

choká bunyaanya

mburí bunyaanya

ng'ondí bunyaanya

ngangá bunyaanya

tindí bunyaanya

ngukú bunyaanya gloss

'sticks'

'walking sticks'

'forests'

'hands'

'spears'

'days'

'dogs'

'snakes'

'goats'

'sheep'

'guinea fowl'

'tomatoes'

'chickens'

the vowel is short so delinking of $\mathrm{H}$ is allowed, as in mizatá bunyaanya. What remains unexplained at the moment, and ultimately remains a lexically exceptional property of the numeral bunyaanya, is why the penult $\mathrm{H}$ spreads only once, not twice, as is the general pattern. Parallel to the alternation kutáálá 'to count', kutala mábaanu 'to count arrows', one would expect *mizata búnyaanya. This restriction on Cross-Junctural Spreading, that it does not spread $\mathrm{H}$ across a word boundary into bunyaanya, has no phonological basis, and other nominal modifiers will be shown to behave differently. Nevertheless, combinations of noun plus bunyaanya have value in unambiguously revealing the underlying tone of nouns; and, furthermore, the non-conformity of this modifier reduces to one fact.

Apart from the tonal parallel with verbs that have underlying final HL and surface as $\mathrm{HH}$, a distributional fact further argues that nouns with final $\mathrm{HH}$ underlyingly have the tone pattern HL. There are no nouns made from monosyllabic roots which have the $\mathrm{HH}$ pattern, although monosyllabic stems appear in the LH (baa-ka) and LL (baa-ndu) classes. Since noun class prefixes do not have underlying $\mathrm{H}$, it would be impossible to combine a monosyllabic root with a noun class prefix and have a $\mathrm{H}$ on the penultimate syllable, since the penult would be the syllable of the class prefix. Therefore, there can be no surface $\mathrm{HH}$ nouns with monosyllabic roots. ${ }^{2}$

Supporting evidence for this tripartite division of nouns into three underlying tone classes, where only two are evident from citation forms, comes from the combination of noun plus adjective. If the noun is of the LL type (as determined from the tonal behavior of the noun before bunyaanya), then when followed by

2 Nouns such as bááná 'children' have a disyllabic vowel-initial stem, e.g. /ba-ána/; compare the singular mwááná 'child', from /mu-ána/. Thus such nouns are not counterexamples to the statement that monosyllabic stems cannot have the surface pattern $\mathrm{HH}$ : these stems are not monosyllabic. 
adjectives such as -laacha or - b'aaha, the noun remains LL and has no effect on the following adjective.

(36) Toneless noun plus adjective

$\begin{array}{ll}\text { bandu balaacha } & \text { 'tall people' } \\ \text { meda milaacha } & \text { 'long rivers' } \\ \text { mabingu mab' aaha } & \text { 'big clouds' } \\ \text { magembe malaacha } & \text { 'long hoes' } \\ \text { mab' ata mab' aaha } & \text { 'big ducks' } \\ \text { magego malaacha } & \text { 'long teeth' } \\ \text { vikoto vib' aaha } & \text { 'big hands' } \\ \text { mbeba mbaaha } & \text { 'big rats' } \\ \text { ndaga ndaacha } & \text { 'long knives' } \\ \text { ng' ombe mbaaha } & \text { 'big cows' } \\ \text { njogolo mbaaha } & \text { 'big roosters' }\end{array}$

On the other hand, if a noun such as one of those in (37) has an underlying final $\mathrm{H}$, as diagnosed by the appearance of $\mathrm{H}$ on the penultimate syllable of bunyaanya in (34), then a level $\mathrm{H}$ appears on the penultimate syllable of the adjective. The same tone pattern is found on nouns with underlying final $\mathrm{H}$ before an adjective in gender 9-10, whose prefix is a non-syllabic nasal on the surface, shown in (38).

(37) Final $\mathrm{H}$ noun plus adjective

bag' osi baláácha

baka bab'ááha

midi miláácha

milamba miláácha

mikate mib'ááha

vikapu vib' ááha

virerende viláácha

vongo vib'ááha

masoka maláácha

(38) nyumba mbááha

mbuba mbááha

ndana ndáácha

tago mbááha

nyungu mbááha 'tall old men'

'big women'

'tall trees'

'tall baobabs'

'big breads'

'big palm baskets'

'long shadows'

'big heads'

'long axes'

'big houses'

'big gardens'

'long bows'

'big hens'

'big pots'

In other words, the tonal behavior of bunyaanya and of adjectives is identical so far; final $\mathrm{H}$ shifts up to two syllables to the right. The data in (38), in particular the fact that the $\mathrm{H}$ does not appear on the final syllable, are consistent with three 
interpretations. First, they may show that the class prefix is an underlying syllabic nasal, thus $\mathrm{H}$ shifts two syllables to the right. Second, if the prefix is underlyingly nonsyllabic they can still be explained by the fact that Cross-junctural spreading does not spread $\mathrm{H}$ to a final syllable, as we have seen previously. Finally, as will be shown later, the adjective stems /bahá/ and /lachá/ have underlying final Hs, which would block spreading to the final syllable. ${ }^{3}$

Adjectives differ from the numeral bunyaanya in terms of tonal behavior after a noun with an underlying penult $\mathrm{H}$ (phrase-final $\mathrm{HH}$ ). A noun with a penult $\mathrm{H}$ loses its $\mathrm{H}$ tone completely, and a $\mathrm{H}$ appears on the first vowel of the following adjective. With nouns outside gender 9-10, this means that the $\mathrm{H}$ appears on the noun class prefix, as in (39). With adjectives in gender 9-10, having the nonsyllabic prefix $\mathrm{N}$-, this means that the underlyingly penult $\mathrm{H}$ appears on the stem initial syllable, as in (40).

(39) Penult $\mathrm{H}$ noun plus adjective

$\begin{array}{ll}\text { mi-zata mí-laacha } & \text { 'long sticks' } \\ \text { mi-senge mí-laacha } & \text { 'long walking sticks' } \\ \text { mi-sidu mí-b'aaha } & \text { 'big forests' } \\ v \text {-ala ví-b' aaha } & \text { 'big hands' } \\ \text { ma-fumu má-laacha } & \text { 'long spears' } \\ \text { ma-tuku má-laacha } & \text { 'long days' }\end{array}$

(40) koshi mbááha

choka ndáácha

mburi mbááha

ng'ondi mbááha

nganga mbááha

tindi mbááha

nguku mbááha

'big dogs'
'long snakes'
'big goats'
'big sheep'
'big guinea fowl'
'big tomatoes'
'big chickens'

In other words, $\mathrm{H}$ tone shifts two syllables to the right, the pattern which is found elsewhere for an underlying penult $\mathrm{H}$, phrase-medially. The form mizata mílaacha is thus parallel to kutala mábaanu 'to count arrows'. The only difference between these various nominal complements is that Spreading does not spread $\mathrm{H}$ from the second to the third vowel across a word if the following word is bunyaanya.

Some adjectives have a penult $\mathrm{H}$ which spreads to the final syllable. Examples standing after a toneless noun are given in (41a). When such an adjective comes after a $\mathrm{H}$-final noun, the $\mathrm{H}$ from the noun spreads to the class prefix of the adjective, as in (41b). The $\mathrm{H}$ can spread only once, because once the $\mathrm{H}$ is on the prefix syllable it abutts the stem initial $\mathrm{H}$, which blocks further spreading. The $\mathrm{H}$

\footnotetext{
3 The final $\mathrm{H}$ is evident even from these data, and explains why the penult has a level $\mathrm{H}$ : compare these examples and forms like nadáája 'I just ate' from /ná-da-já/.
} 
then delinks from the last syllable of the noun. With nouns having a penult $\mathrm{H}$ as in (41c), Spreading (7) and Cross-Junctural Spreading (25) link the $\mathrm{H}$ to the following two syllables, and then the $\mathrm{H}$ undergoes delinking from the noun. The contrast between final and penult $\mathrm{H}$ is thus obliterated before adjectives having a penult $\mathrm{H}$.

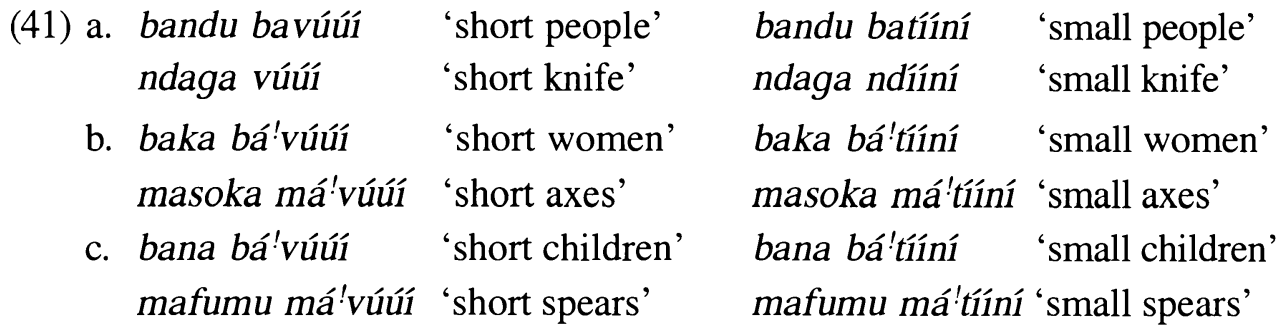

In gender 9-10, the adjective prefix is nonsyllabic (or may be lacking, before a fricative) so there is no place for the $\mathrm{H}$ to spread. As seen in the examples in (42), using a final-H noun (42a) and a penult-H noun (42b), the final syllable of the noun surfaces as $\mathrm{H}$. In the first case, the final $\mathrm{H}$ cannot spread since the following syllable is $\mathrm{H}$. Since the $\mathrm{H}$ remains singly-linked, it also cannot undergo Delinking; therefore, the underlying tone is unaffected. Such data then confirm the hypothesis that these nouns have an underlying final $\mathrm{H}$ tone, a conclusion arrived at on the basis of the fact that they induce the addition of a $\mathrm{H}$ on a following modifier. The presence of a downstep between the $\mathrm{Hs}$ is due to the fact that two $\mathrm{H}$ autosegments concatenated at the surface are always separated by a downstep. In the second case, the underlyingly penult $\mathrm{H}$ spreads to the final syllable, but no further, and delinking removes the $\mathrm{H}$ from its underlying position.
a. ndaná 'vưúí
'short bow'
ndaná 'ndíiní
'small bow'
b. choká 'vưúí
'short snake'
choká 'ndíiní
'small snake'

Apart from the numeral " 8 " as noted above and " 2 " and " 4 " which have special properties and will be discussed in the final section, numerals behave tonally like adjectives. After LL-final nouns, the basic tone of the numeral is revealed, as in (43).
mundu gumwéérí
'one person'
bandu badáádú 'three people'
bandu basáánú
'five people'
bandu barandáádú '
'six people'
bandu mfungáádé
'seven people'
bandu ikeenda
'nine people'
bandu ikúúmí
'ten people'

The $\mathrm{H}$ of a $\mathrm{H}$-final noun shifts at least to the following syllable and shifts to a following syllable if that syllable is toneless (as in the numerals "6", "9"), shown in (44). 


$\begin{array}{llll}\text { (44) ndana í'mwéerí } & \text { 'one bow' } & \text { ndana î'dáádú 'three bows' } \\ \text { ndana í'sáánú } & \text { 'five bows' } & \text { ndana irá'ndáádú 'six bows' } \\ \text { ndana mfú'ngáádé } & \text { 'seven bows' } & \text { ndana ikéénda } & \text { 'nine bows' } \\ \text { ndana í'kúúmí } & \text { 'ten bows' } & & \end{array}$

If the preceding noun has $\mathrm{H}$ underlyingly on the penult, the $\mathrm{H}$ shifts to first syllable of the numeral, as in (45).

$\begin{array}{llll}\text { choka î́mwéérí } & \text { 'one snake’ } & \text { choka í'dáádú } & \text { 'three snakes' } \\ \text { choka î'sáánú } & \text { 'five snakes' } & \text { choka írandáádú } & \text { 'six snakes' } \\ \text { choka ḿfungáádé } & \text { 'seven snakes’ } & \text { choka íkeenda } & \text { 'nine snakes' } \\ \text { choka í'kúúmí } & \text { 'ten snakes' } & & \end{array}$

In some cases (ndana í'mwéérí, choka í'mwéérî) it is impossible to reconstruct the location of the underlying tone from the phrasal tone, because a $\mathrm{H}$ in the modifier blocks shift of $\mathrm{H}$ (the extent of shifting generally reveals the underlying location of the $\mathrm{H}$ ), but in other cases where the stem does not begin with a $\mathrm{H}$ tone (ndana irá'ndáádú, choka írandáádû) the extent of $\mathrm{H}$ shift reveals whether the tone is underlyingly on the penult or final syllable. When the $\mathrm{H}$ tone shifts from the noun to the stem of the numeral, the $\mathrm{H}$ must have originated from the final syllable of the noun (/ndaná/), and when the $\mathrm{H}$ shifts only to the numeral's prefix the $\mathrm{H}$ must have originated from the penultimate syllable of the noun (/chóka/).

The underlying distinction between the three lexical tone classes of nouns is further motivated by the tonology of nouns which are preceded by the $\mathrm{H}$ toned copula $n i$. A H tone appears on a noun which stands after the copula, and in many cases, the copula itself also has a $\mathrm{H}$. The underlying tone of the noun can be determined by inspecting the form of the noun before bunyaanya, so " $8 \mathrm{~N}$ 's" is given to motivate the underlying tone in the examples below. First we consider nouns of the LL class. If the noun is disyllabic, a $\mathrm{H}$ appears on $n i$ - and on the following syllable, where it is realized as a falling tone.

$\begin{array}{llll}\mathrm{N} & \text { '8 Ns' } & \text { 'it is N' } & \text { gloss } \\ \text { baandu } & \text { bandu bunyaanya } & \text { ní báandu } & \text { 'people' } \\ \text { miizi } & \text { mizi bunyaanya } & \text { ní míizi } & \text { 'villages' } \\ \text { ndaaga } & \text { ndaga bunyaanya } & \text { ní ndáaga } & \text { 'knives' } \\ \text { ng'oombe } & \text { ng'ombe bunyaanya } & \text { ní ng'óombe } & \text { 'cows' }\end{array}$

This is parallel to the pattern of spreading in other contexts. The $\mathrm{H}$ does not delink from the copula, since the following syllable has a falling tone. The $\mathrm{H}$ spreads only to the penult, not two syllables rightward to the final syllable, since spreading to a second vowel by Cross-Junctural Spreading cannot target a prepausal syllable. 
If the noun is trisyllabic, as in (47), there is no $\mathrm{H}$ on $n i$, but there is a $\mathrm{H}$ on the following two syllables, with the $\mathrm{H}$ being realized as a falling tone on the penult. Based on analogous examples of final $\mathrm{H}$ plus a trisyllabic span drawn from combinations of noun plus adjective or bunyaanya, one would expect $\mathrm{H}$ to spread to the following two syllables, as it does. The $\mathrm{H}$ does delink from the copula, but since the antepenult is followed by a falling tone, the antepenultimate $\mathrm{H}$ linkage is retained, yielding a mixed pattern of shifting and spreading that is analogous to word-internal examples such as nadálima 'I just cultivated' from /nádalima/.

$\begin{array}{llll}\mathrm{N} & \text { '8 Ns' } & \text { 'it is } \mathrm{N} \text { ' } & \text { gloss } \\ \text { mageembe } & \text { magembe bunyaanya } & \text { ni mágéembe } & \text { 'hoes' } \\ \text { mabiingu } & \text { mabingu bunyaanya } & \text { ni mábíingu } & \text { 'clouds' } \\ \text { njogoolo } & \text { njogolo bunyaanya } & \text { ni njógóolo } & \text { 'roosters' }\end{array}$

Finally, if the noun after the copula is longer than trisyllabic, the $\mathrm{H}$ spreads from the copula two syllables to the right, to a syllable which precedes the penult. Thus even with spreading by two syllables, the $\mathrm{H}$ tone does not form part of a contour. Therefore nothing blocks Delinking, and the surface pattern is shifting rather than spreading.
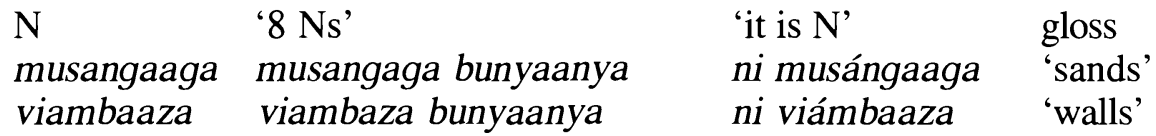

Now we consider nouns of the final-H group after the copula. With these nouns a $\mathrm{H}$ appears on the first syllable of the noun if it is disyllabic, as in (49). Note that the $\mathrm{H}$ from the copula appears on the phrasal penult as a level $\mathrm{H}$, not a falling tone, in contrast to analogous nouns with no underlying final $\mathrm{H}$ in (46). The level $\mathrm{H}$ is due to the fact that underlyingly, the final syllable has a $\mathrm{H}$, and therefore a falling tone cannot be created on the penult - an analogous situation arises strictly within the word in the recent past tense of monosyllabic $\mathrm{H}$ stems, such as [nadáája] from /nádajá/. Given that the penult has a level $\mathrm{H}$, not a fall (explained by the underlying $\mathrm{H}$ on the final syllable), then the condition for delinking the $\mathrm{H}$ from the copula's syllable is satisfied, so we have surface shifting, and not just spreading. Thus, /ní midí/ becomes ní míí'dí by Spreading, ní-míidi by Final H Deletion, and surface [ni míídi] by Delinking.

$\begin{array}{llll}\mathrm{N} & \text { '8 Ns' } & \text { 'it is N'} & \text { gloss } \\ \text { miidi } & \text { midi bunyáánya } & \text { ni míidi } & \text { 'trees' } \\ \text { voongo } & \text { vongo bunyáánya } & \text { ni vóóngo } & \text { 'heads' } \\ \text { nyuumba } & \text { nyumba bunyáánya } & \text { ni nyúúmba } & \text { 'houses' }\end{array}$


If a final-H noun after the copula has more than two syllables as in (50), the $\mathrm{H}$ from the copula spreads two syllables to the right, and the left branches of the $\mathrm{H}$ tone are delinked. In the case of underlying /ní masoká/, Spreading results in $n i$ másooká, Cross-Junctural Spreading gives ní másóó'ká, and Final H Deletion gives ní másóóka. Because the penult does not fall, Delinking applies maximally, and the surface form that emerges is [ni masóóka]. Similar derivations obtain for polysyllabic stems as in ni viréreende.

\begin{tabular}{|c|c|c|c|}
\hline (50) $\begin{array}{l}\mathrm{N} \\
\text { masooka } \\
\text { nyamaandu } \\
\text { virereende } \\
\text { sufuriia }\end{array}$ & $\begin{array}{l}\text { ‘8 Ns' } \\
\text { masoka bunyáánya } \\
\text { l nyamandu bunyáánya } \\
\text { virerende bunyáánya } \\
\text { sufuria bunyáánya }\end{array}$ & $\begin{array}{l}\text { 'it is } \mathrm{N} \text { ' } \\
\text { ni masóóka } \\
\text { ni nyamáándu } \\
\text { ni viréreende } \\
\text { ni sufúriia }\end{array}$ & $\begin{array}{l}\text { gloss } \\
\text { 'axes' } \\
\text { 'animals' } \\
\text { 'shadows' } \\
\text { 'pan' }\end{array}$ \\
\hline
\end{tabular}

Finally, if the noun is in the penult-H class (final $\mathrm{HH}$ prepausally), the $\mathrm{H}$ from $n i$ is separated from the lexical $\mathrm{H}$ of the noun by a downstep. If the noun is disyllabic, the $\mathrm{H}$ remains on the copula, since the following syllable already bears a $\mathrm{H}$ tone, as shown in (51).

$\begin{array}{llll}\mathrm{N} & \text { '8 Ns' } & \text { 'it is N’} & \text { gloss } \\ \text { méérí } & \text { merí bunyaanya } & n i ́ ! \text { méérí } & \text { 'moons' } \\ \text { ngóóló } & \text { ngoló bunyaanya } & n i ́ \text { ' ngóóló } & \text { 'hearts' } \\ \text { mbúúrí } & \text { mburí bunyaanya } & n i ́ \text { ' mbúúrí } & \text { 'goat' } \\ \text { chóóká } & \text { choká bunyaanya } & n i ́ \text { ' chóóká } & \text { 'snake' }\end{array}$

On the other hand, if the noun is longer than two syllables, the $\mathrm{H}$ spreads to the right and delinks from the copula.

(52)

$\begin{array}{ll}\mathrm{N} & \text { '8 Ns' } \\ \text { mafúúmú } & \text { mafumú bunyaanya } \\ \text { mikóónú } & \text { mikonú bunyaanya } \\ \text { marúúbá } & \text { marubá bunyaanya }\end{array}$

'it is $\mathrm{N}$ '

ni má'fúúmú

ni mí'kóónú

ni má'rúúbá gloss

'spears'

'arms'

'days'

The same patterns are found in nouns which follow verbs that have a final grammatical $\mathrm{H}$, such as verbs in the imperative. This melodic $\mathrm{H}$ deletes prepausally as in (53a), but its presence can be recovered phrasally. Before a toneless disyllabic noun as in (b), the $\mathrm{H}$ spreads to the phrasal penult in the noun, and before a trisyllabic toneless noun as in (c), the $\mathrm{H}$ delinks from the verb, but not the prepenult syllable, due to the falling tone on the penult. 

(53) a. taala
b. talá báandu
'count!'
talá míizi
'count people!'
talá máago
'count villages!'
c. tala bálíimi
'count stones!'
tala mínyáango
'count farmers!'
tala mágéembe
'count doors!'
tala njógóolo
'count hoes!'
'count roosters!'

When followed by a disyllabic or trisyllabic noun that has an underlying final $\mathrm{H}$ as in (54a), the $\mathrm{H}$ appears on the penult as a level $\mathrm{H}$, and, since the penult does not fall, the $\mathrm{H}$ can delink from the vowels on the left. If the following noun has more than three syllables, as in (b), $\mathrm{H}$ spreads a maximum of two syllables to the right and delinks on the left, since no falling tone is created. If the noun has a phonetically realized $\mathrm{H}$ on the first syllable, as in (c), the $\mathrm{H}$ from the verb cannot spread, so the underlying final $\mathrm{H}$ surfaces as such on the verb. Finally, in (d) the second syllable of the noun has a $\mathrm{H}$, so the verbal $\mathrm{H}$ spreads to the first syllable of the noun and delinks from the verb. In both (c) and (d), the $\mathrm{H}$ of the verb (whether it is realized within the verb or shifts to the noun) is separated from the noun's lexical $\mathrm{H}$ by a downstep.
a. tala bááka
'count women!'
tala míidi
'count trees!'
tala masóóka
'count axes!'
b. tala sufúriia
'count pans!'
tala viréreende
'count shadows!'
c. talá 'bááná
'count children!'
talá 'váálá
'count fingers!'
talá 'sáb'úuni
'count soap!'
d. tala má'túúkú
'count days!'
tala sá'máákí
'count fish!'

As observed earlier in discussing the data of (39)-(40), when a noun with a penult $\mathrm{H}$ is followed by an adjective, the $\mathrm{H}$ spreads into the adjective and delinks from the noun (e.g., kamba ndáácha 'long rope', mi-zata mí-laacha 'long sticks'). It is predicted that if the $\mathrm{H}$ of such a noun were also immediately preceded by a $\mathrm{H}$ in the previous word, that $\mathrm{H}$ would block delinking. The data in (55) show that this prediction is correct. 
(55)

ní 'kóshí mbááha

ní 'chóká ndáácha

ni mí-'zátá mí-laacha

tala má-'fúmú má-laacha

talá 'mbúrí mbááha 'it is big dogs'

'it is long snakes'

'it is long sticks'

'count long spears!'

'count big goats!'

Beginning with /ní kóshi mbahá/, the two spreading rules apply, assigning $\mathrm{H}$ to the second syllable of the noun and to the first syllable of the adjective. Because the multiply-linked $\mathrm{H}$ happens to be preceded by a $\mathrm{H}$, delinking does not apply and the form surfaces as [ní 'kóshí mbááha], after deletion of the final $\mathrm{H}$ from the adjective.

\section{Complications with non-adjectival modifiers}

The behavior of certain nominal modifiers poses complications, centering around what happens when Hs come together underlyingly. In some cases within the noun phrase, one of the Hs deletes. One context where dissimilative $\mathrm{H}$ deletion occurs is before possessive pronouns. Nouns followed by the $1 \mathrm{sg}$. possessive pronoun fall into two behavioral tone groups. When nouns of either the LL or final $\mathrm{H}$ tone classes are followed by "my", the noun is toneless and the possessive pro-noun has a surface $\mathrm{HH}$ tone pattern.

(56) LL nouns

igembe jáápó 'my hoe'

kijiko cháápó 'my spoon'

magembe gáápó 'my hoes'

vijoko váápó 'my spoons'

LH nouns

isoka jáápó 'my axe'

masoka gáápó

'my axes'

kirerende cháápó 'my shadow'

virerende váápó

'my shadows'

In this context, it is impossible to determine whether the final vowel of the noun has a $\mathrm{H}$ : no $\mathrm{H}$ surfaces on the noun, and the tone of the following modifier does not change as a function of the underlying tone of the preceding noun. However, we know from other evidence, such as the appearance of $\mathrm{H}$ on following words viz. masoka maláácha 'long axes' (vs. magembe malaacha 'long hoes') that the second set of nouns has an underlying final $\mathrm{H}$.

Partial disambiguation of the tone classes is seen with nouns having a penult $\mathrm{H}$ tone, as in (57); these nouns surface with a final $\mathrm{H}$ separated from the $\mathrm{H}$ of the possessive pronoun by a downstep. Since the pronoun has $\mathrm{H}$, one would not expect the $\mathrm{H}$ on the noun to spread into the pronoun. 
(57) HH nouns
chalá 'cháápó 'my hand'
ifumú !jáápó
'my spear'
$\begin{array}{ll}\text { valá 'váápó } & \text { 'my hands' } \\ \text { mafumú 'gáápó } & \text { 'my spears' }\end{array}$

We must now explain the loss of the final $\mathrm{H}$ from underlying masoká gáápó. Most previous examples of adjacent Hs have involved Spreading, for example $n i$ má'fúúmú 'they are spears' from /ní mafúmu/. Combinations of $\mathrm{H}+\mathrm{H}$ created at the underlying level are also found, for example involving the copula /ní/ or a verb in the imperative plus a H-initial noun, cf. ní 'sáb'úuni 'it is soap', talá 'sáb'úuni 'count soap!'. These data show that there is no general deletion of $\mathrm{H}$ next to $\mathrm{H}$. Data in (42b) such as ndaná 'vúúi 'short bow' from /ndaná vúi/ show that even between noun and adjective, adjacent $\mathrm{Hs}$ that arise from phrasal concatenation are not subject to any $\mathrm{H}$ tone deletion. Such reduction of multiple underlying $\mathrm{Hs}$ is limited to combinations of noun plus certain modifiers, whose nature we discuss later. For now, we note that loss of $\mathrm{H}$ in masoka gáápó (*masoká 'gáápó) is one such instance of regressive deletion of $\mathrm{H}$, a process which will be documented further in this section. In light of the fact that there is no regressive deletion of $\mathrm{H}$ before $\mathrm{H}$ in mafumú !gáápó 'my spears' from /mafúmu gáápó/, we also conclude that this deletion process only operates on underlyingly adjacent $\mathrm{H}$ tone sequences. We tenatively formulate this process as in (58).

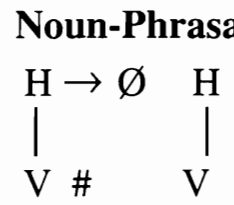

There are two surface tonal patterns in the $1 \mathrm{sg}$. possessive pronoun, governed by the noun class of the agreement prefix. The $1 \mathrm{sg}$. possessive pronoun is composed of a class prefix which agrees with the head noun (e.g., $j$ - in cl. 5, $g$-in cl. 6) plus the possessive stem (-apo for $1 \mathrm{sg}$.). If the agreeing pronoun is in class 1 or 9 , a tone pattern different from the preceding is encountered. ${ }^{4}$ When preceded by a noun with final LL, a possessive pronoun in classes 1 or 9 surfaces with the tone pattern LL. In contrast, the same noun stems in the plural, which are in classes 2 and 10 , exhibit the surface pattern $\mathrm{HH}$ as above.

$\begin{array}{ll}\text { Cl. } 1,9 \text { after } \mathrm{LL} \text { noun } \\ \text { mundu waapo } & \text { 'my person' } \\ \text { mdabana waapo } & \text { 'my youth' } \\ \text { ng'ombe yaapo } & \text { 'my cow' } \\ \text { njogolo yaapo } & \text { 'my rooster' }\end{array}$

Cl. 2,10 after LL noun bandu báápó 'my people' badabana báápó 'my youths' ng'ombe ráápó 'my cows' njogolo ráápó 'my roosters'

\footnotetext{
4 This patterning in the tone of non-adjectival modifiers is found in many Bantu languages, and often includes cl. 4. In Taita (as well as some other Bantu languages) cl. 4 in the agreement system has been replaced with cl. 10 .
} 
Possessive pronouns in classes other than 1 or 9 have underlying $\mathrm{H}$ on the penult, which spreads to the final syllable, accounting for the surface $\mathrm{HH}$ pattern. At this point, we cannot be certain of the underlying tone of po, which could be underlyingly toneless and take its $\mathrm{H}$ from Spreading, but other evidence will show that it has $\mathrm{H}$. Assuming final $\mathrm{H}$, the $\mathrm{H}$ would be expected to delete prepausally in mundu waapo. In data such as bandu báápó, the $\mathrm{H}$ could delete by a tonal dissimilation process, Meeussen's Rule, where underlying $\mathrm{HH} \rightarrow \mathrm{H} \emptyset$; the penult $\mathrm{H}$ would then spread to the final syllable, just as /kutála/ $\rightarrow$ [kutáála] 'to count'. Another interpretation of báápó is that the penult and final Hs fuse into one, i.e., deletion of final $\mathrm{H}$ after $\mathrm{H}$ and association of the penult $\mathrm{H}$ to the final derives from a single fusion operation.

We now consider evidence that the final tone is $\mathrm{H}$. If the noun preceding a cl. 1 or 9 possessive pronoun has underlying final $\mathrm{H}$, then the $\mathrm{H}$ of the noun shifts once to the right, to the initial syllable of the pronoun, as seen in (60). The level $\mathrm{H}$ in the first column is explained if po has underlying $H$, thus [ndana yáápo] derives from /ndaná ya-pó/. Spreading operates as expected, and because of the underlying final $\mathrm{H}$, the penult $\mathrm{H}$ cannot be realized as a falling tone. This allows delinking of the $\mathrm{H}$ from the final syllable of the noun; deletion of the prepausal $\mathrm{H}$ gives the surface form.

LH noun before cl. 1,9

mg'osi wáápo 'my elder'

ndana yáápo 'my bow'

mbuba yáápo 'my garden'

muka wáápo
LH noun before other classes bag'osi báápó 'my elders' ndana ráápó 'my bows' mbuba ráápó 'my gardens' baka báápó 'my wives'

Postulating a final $\mathrm{H}$ on the syllable po also explains why a following adjective receives $\mathrm{H}$ tone after that possessive pronoun.
(61)
kaamba
kamba yaapo
'rope'
muundu
'my rope'
'person'
kamba ndaacha
'long rope'
kamba yapo ndáácha
mundu mlaacha
'my long rope'
mundu wapo mláácha 'my tall person'
'tall person'
mundu waapo 'my person'

From this evidence, we conclude that both syllables of báápó are underlyingly $\mathrm{H}$ toned and, consequently, the final $\mathrm{H}$ deletes by Meeussen's Rule; alternatively the Hs fuse.

The same analysis holds for nouns with penult $\mathrm{H}$ (citation $\mathrm{HH}$ ): penult $\mathrm{H}$ shifts two syllables to the right, as in (62). Spreading and Cross-Junctural Spreading give intermediate mwáná wáá'pó, delinking results in mwana wáá'pó, and the surface form comes from deletion of the prepausal $\mathrm{H}$. 
(62) HH noun before cl. 1,9

mwana wáápo 'my child'

koshi yáápo 'my dog'

nganga yáápo 'my guinea fowl'
HH noun before other classes

baná 'báápó 'my children'

koshí 'ráápó 'my dogs'

ngangá 'yáápo 'my guinea fowls'

Two other modifiers have the same tonal behavior, the numeral "four" and the quantifier "some". We first consider the numeral "four". When the preceding noun is of the LL or LH class, as in $(63 a, b)$, no $\mathrm{H}$ appears on the noun and the numeral has the tone pattern $\mathrm{HH}$.

a. LL nouns

bandu b'ááná 'four people'

miri ínyá 'four roots'

ng'ombe íinyá 'four cows'

b. LH nouns

baka b'áná 'four women'

bag' osi b'ááná 'four elders'

vongo viíná 'four heads'

Given the phrasal dissimilation rule (58), underlying /baká b'ána/ undergoes regressive dissimilation so the two tone classes are neutralized in (63). If the preceding noun has an underlying penultimate $\mathrm{H}$ tone, that $\mathrm{H}$ shifts to the final syllable of the noun and is separated from the $\mathrm{H}$ of the numeral by a downstep. $\mathrm{H}$ is not deleted in (64) because it is underlyingly on the penult and thus not adjacent to the initial $\mathrm{H}$ of the modifier.
(64) mesó 'ááná
'four eyes'
koshí 'î́nyá
'four dogs'
ngoló 'ínyá
'four hearts'

This pattern is also found before the quantifier "some", where the example in (65a) illustrates LL nouns, (65b) gives LH nouns, and (65c) gives HH nouns.
a. bandu báám
'some people'
magembe gáám
'some hoes'
ng'ombe rímm
'some cows'
mizi ríím
'some villages'
b. baka bááḿ
'some women'
masoka gáám
'some axes'
midi ríím
'some trees' 

c. mikonú 'ríím
'some arms'
mariná 'gáám
'some names'
valá 'viímí
'some hands'

The quantifiers "how many" exhibit special tonal behavior. After a toneless noun, the modifier -liinga is toneless, as in (66). Surprisingly, it remains toneless after a $\mathrm{H}$-final noun, as in (67). It is expected that the final $\mathrm{H}$ should shift into the modifier, but it does not, and instead it disappears entirely.
(66) bandu baliinga
vijiko viliinga
'how many people?'
ng' ombe iliinga
'how many spoons?'
miri iliinga
'how many cows'
'how many roots'
(67) baka baliinga
masoka aliinga
midi iliinga
'how many women?'
vikapu viliinga
'how many axes?'
'how many trees?'
'how many baskets?'

A noun with an underlying penult $\mathrm{H}$ surfaces with the final tone pattern $\mathrm{LH}$ before this modifier. Note that Cross-junctural Spread does not apply to -liinga.
(68) merí iliinga
'how many months?'
mariná aliinga
'how many names?'
valá viliinga
'how many fingers?'
koshí iliinga
'how many dogs?'

The quantifiers "many" and "all" also have anomalous tone paterns. The underlying tone of these quantifiers is best revealed in (69) when preceded by a toneless noun. The modifier stems have a penult $\mathrm{H}$. As expected, the penultimate $\mathrm{H}$ of $\mathrm{HH}$ nouns shifts to the final syllable of the noun, shown in (70).
(69) bandu bééngí
'many people'
bandu bóósé
'all people'
miri nyíingí
'many roots'
miri yóósé
'all roots'
ndaga nyíingí 'many knives'
ndaga róósé
'all knives'
magembe mééngi 'many knives'
magembe góosé
'all hoes'
(70) mizatá 'nyíi
valá 'víingí
'many sticks'
mizatá 'yóósé
'all sticks'
koshí 'nyíingí
'many fingers'
valá 'vóósé
'all fingers'
koshí 'róósé
'all dogs' 
Unexpectedly, nouns with final $\mathrm{H}$ tone retain that $\mathrm{H}$, and the $\mathrm{H}$ tone of the following quantifier is deleted.

$\begin{array}{llll}\text { (71) } & \text { baká beengi } & \text { 'many women' } & \text { baká boose 'all girls' } \\ \text { midá nyiingi } & \text { 'many trees' } & \text { midí yoose 'all trees' } \\ \text { masoká meengi } & \text { 'many axes' } & \text { masoká goose 'all axes' } \\ \text { vongó viingi } & \text { 'many heads' } & \text { vongó voose } & \text { 'all heads' } \\ \text { mbubá nyiingi } & \text { 'many gardens' } & \text { mbubá roose } & \text { 'all gardens' }\end{array}$

The final tonal complication in noun phrasal tonology concerns the behavior of the numeral "two", which interacts with the tone of the preceding noun in a special way. When it is preceded by a LL-final noun, as in (72), it surfaces with no $\mathrm{H}$ tones, as expected. If the preceding noun is of the $\mathrm{HH}$ class, i.e., has an underlying penultimate $\mathrm{H}$ tone, as in (73), then that $\mathrm{H}$ shifts from the noun and appears on the penultimate syllable of the numeral.

(72) LL nouns

$\begin{array}{ll}\text { bandu baabi } & \text { 'two people' } \\ \text { miri iibi } & \text { 'two roots' } \\ \text { magembe aabi } & \text { 'two hoes' } \\ \text { vijoko viibi } & \text { 'two spoons' } \\ \text { ng' ombe iibi } & \text { 'two cows' }\end{array}$

(73) HH nouns

bana báábi

'two children'

meri ííbi

'two months'

mikonu íibi

'two arms'

marina áábi

'two names'

vala víibi

'two fingers'

koshi íibi

'two dogs'

Unexpectedly, an underlyingly final $\mathrm{H}$ on the preceding noun disappears entirely and does not shift to the modifier, as in (74).

(74) LH nouns

$\begin{array}{ll}\text { baka baabi } & \text { 'two women' } \\ \text { bai baabi } & \text { 'two girls' } \\ \text { midi iibi } & \text { 'two trees' } \\ \text { minazi iibi } & \text { 'two coconut trees' } \\ \text { masoka aabi } & \text { 'two axes' }\end{array}$


The anomalous modifier patterns are summarized as follows. An underlying final $\mathrm{H}$ deletes before a $\mathrm{H}$-initial possessive pronoun, the numeral "4", and "some". Nouns have the same behavior before "how many", even though that modifier does not have a surface $\mathrm{H}$. The quantifiers "all" and "many" also have an underlying initial $\mathrm{H}$ tone, but rather than causing deletion of the preceding $\mathrm{H}$, the $\mathrm{H}$ of the modifier deletes (additionally, the final $\mathrm{H}$ of the noun does not shift into the quantifier). Finally, a final $\mathrm{H}$ deletes before the numeral " 2 ", rather than shifting into the numeral (even though a penult $\mathrm{H}$ does shift into that numeral).

The main anomaly in the data is deletion of underlying final $\mathrm{H}$ before a modifier $\mathrm{H}$. Such dissimilation is not in itself puzzling, but the restriction of the triggering class is. Some surface $\mathrm{H}$-inital nominal modifiers are not in the triggering class, so examples such as ndaná 'vúúi 'short bow' in (42) do not show deletion of the final $\mathrm{H}$. Underlyingly, this comes from /ndaná n-vúi/, with a noun class prefix composed of a preconsonantal nasal; this nasal is deleted before a stem-initial fricative. If this prefix were underlyingly syllabic, then the two Hs would not be in adjacent syllables at that level, and the lack of dissimilative lowering could be explained on the basis of the non-adjacency of the tones. There is one factor which might seem to weigh against that analysis, in the form of evidence that this noun class prefix does not behave phonologically as though it were syllabic. We have previously observed the behavioral contrast in penult-H nouns with respect to the location of the shifted $\mathrm{H}$ in data such as ma-fumu má-laacha 'long spears' from (39) versus choka ndáácha 'long snakes' from (40), where the nonsyllabicity of the class prefix in ndáácha explains why the tone appears on the penult. This argues that the nasal is not syllabic at the stage where Cross Junctural spreading applies. However, if preconsonantal nasals are syllabic only at the stage where dissimilation takes place, and desyllabify after dissimilation of $\mathrm{H}$, then there is no obstacle to appealing to the underlying syllabicity of the nasal in explaining the difference between ndaná 'vúúi and ndana yáápo.

One of the modifiers which exhibits an exceptional pattern is "many", whose stem is underlying /ingi/. A noun class paradigm of this modifier is given in (75). The class 10 form contains the same prefix $\mathrm{N}$ - found in adjectives such as ndáácha and ndíní and as we have seen, that nasal blocks tonal dissimilation. The important difference between ndíní which does not participate in dissimilation and nyíngí which does, is that the nasal is preconsonantal in ndíiní and prevocalic in nyíngí. This indicates that, if syllabicity of the nasal is the explanation for the fact that ndíní does not participate in dissimilation, syllabicity is only assigned to a preconsonantal nasal and not to a prevocalic one.

$\begin{array}{lllll}\text { (75) } & \text { cl. } 2 & \text { bééngí } & \text { cl. } 4 & \text { míngí } \\ \text { cl. } 6 & \text { mééngí } & \text { cl. } 8 & \text { víingí } \\ \text { cl. } 10 & \text { nyíingí } & & \end{array}$


As noted above, the modifier -liinga 'how many' behaves like the numeral "4" and we could explain its behavior by presuming that the agreement prefix has an underlying $\mathrm{H}$ tone which is deleted, but there is no other motivation for positing a $\mathrm{H}$ on the agreement prefix. If we suppose that the underlying form of masoka aliinga 'how many axes?' is /masoká áliinga/ and the underlying form of mariná aliinga 'how many names?' is /marína áliinga/, then by applying rules which are independently motivated, plus a rule deleting the $\mathrm{H}$ from the agreement prefix, we can trigger the deletion of final $\mathrm{H}$ in masoka and limit the extent of Spreading in masoká; whether this is sufficient motivation for positing an abstract $\mathrm{H}$ tone on the prefix is a broader issue which cannot be resolved here.

As for the behavior of the quantifiers "many" and "all", the irregularity can be captured in the generalization that the underlying phrasal $\mathrm{HH}$ sequence is resolved in this case by deletion of the $\mathrm{H}$ of the modifier, not that of the noun (masoká meengi 'many axes', masoká goose 'all axes', cf. masoka gáápó 'my axes', masoka gáám 'some axes'). This fact has no phonetic explanation, but may relate to the fact that they are quantifiers, and quantifiers sometimes have unexpected patterns of behavior in the phrasal tone sandhi of Bantu languages (see Odden [1994]).

Finally, the best explanation of the behavior of " 2 "- - the fact that $\mathrm{H}$ shifts from the penult of a noun to the prefix (marina áábi 'two names') but deletes when the $\mathrm{H}$ is underlyingly on the final noun syllable (masoka aabi 'two axes') -is historical. The numeral stem was originally disyllabic *bili, but deletion of $l$, resolution of vowel hiatus, and shortening of final vowels resulted in the loss of the final syllable. Originally, one would have encountered alternations such as * masoka abíli from /masoká abili/ and *marina ábili from /marína abili/. After loss of the final syllable, these forms would surface as *masoka abí and *marina ábi, which would be subject to deletion of final $\mathrm{H}$, a process that would give masoka abi and marina ábi, the surface forms of the actual language, once penultimate lengthening is factored in.

\section{Summary}

The preceding analysis of the tonal system of the Dembwa dialect of Taita has revealed that the bulk of tonal alternations in the language can be understood in terms of two simple operations, tone spreading and tone delinking. Tone spreading is manifested in the form of two separate rules, one a rather general rightward spread rule and the other a more restricted one which applies only in what might be called a "morphosyntactically derived" environment. Delinking eliminates the left branch of a multiply-linked $\mathrm{H}$, subject to three phonological restrictionsdelinking does not apply after another $\mathrm{H}$, it does not target a long vowel, and it does not apply if the result would be a simple falling tone. It is not obvious how these conditions should be expressed in a formal theory of phonological operations; thus, the analysis of Taita tone potentially bears on important theoretical questions, in particular whether output conditions are necessary on rules and, if so, what constitutes a possible output condition on a rule. Detailed discussion of that issue is 
orthogonal to the purpose of this paper, which is to state what the facts of Taita are that an adequate theory must account for.

\section{REFERENCES}

Batibo, Herman. 1991. "The two-directional tone melody spread in Sukuma." In Kathleen Hubbard (ed.), Proceedings of the Seventeenth Annual Meeting of the Berkeley Linguistics Society: Special session on African Language Structures, BLS: Berkeley. Pp. 15-24.

Clements, G. N. and Kevin Ford. 1979. "Kikuyu tone shift and its synchronic consequences." Linguistic Inquiry 10: 179-210.

Coupez, Andre. 1955. Esquisse de la langue holoholo. Annalen van het Koninklijk Museum van Belgisch-Congo, Tervuren. v. 12.

Downing, Laura. 1990. "Problems in Jita tonology." Doctoral dissertation, University of Illinois: Urbana.

Goldsmith, John. 1976. “Autosegmental phonology.” Doctoral dissertation, MIT. Distributed by Indiana University Linguistics Club.

Goldsmith, John. 1985. "On tone in Sukuma." In Didier Goyvaerts (ed.), African Linguistics: Essays in memory of M.W.K. Semikenke, Benjamins: Amsterdam. Pp. 167-187.

Idsardi, William and Thomas Purnell. 1995. "Sukuma Accent." Proceedings of the Chicago Linguistic Society 31: 217-230.

Kang, Yoonjung. 1997. “Tone in Sukuma." In Benjamin Bruening, Yoonjung Kang and Marth McGinnis (eds.), PF: Papers at the interface, MIT Working Papers in Linguistics 30: 49-95. MIT: Cambridge.

Kenstowicz, Michael and Charles Kisseberth. 1988. "Chizigula Tonology-the word and beyond." MS, University of Illinois.

Kisseberth, Charles and David Odden. To appear. "Tone." In Derek Nurse and Gerard Phillipson (eds.), The Bantu Languages, Curzon: Surrey.

Massamba, David P. 1982. "Aspects of accent and tone in Ci-Ruri." Doctoral dissertation, Indiana University: Bloomington. 
McHugh, Brian. 1990. "Cyclicity in the phrasal phonology of Kivunjo Chaga." Doctoral dissertation, UCLA: Los Angeles.

Nurse, Derek and Gerard Phillippson. 1977. "Tones in Old Moshi (Chaga)." Studies in African linguistics 8,1: 49-80.

Odden, David. 1982. "Tonal phenomena in Kishambaa." Studies in African linguistics 13.2: 177-208.

Odden, David. 1985. "Three dialects of Kipare.” In Gerritt Dimmendaal (ed.), Current Approaches to African Linguistics, Vol. 3, Foris, Dordrecht. Pp. 257280.

Odden, David. 1994. "Syntactic and semantic conditions in Kikongo phrasal phonology." In Jennifer Cole and Charles Kisseberth (ed.), Perspectives in Phonology, CSLI: Stanford. Pp. 167-201.

Odden, David. 1996. The Phonology and Morphology of Kimatuumbi. Clarendon Press: Oxford.

Odden, David. 1998a. "Verbal tone melodies in Kikerewe." In Thomas Hinnebusch and Ian Maddieson (eds.), Theoretical Approaches to African Linguistics II, Red Sea Press: New Brunswick. Pp. 177-184.

Odden, David. 1998b. "Principles of tone assignment in Tanzanian Yao." In Larry Hyman and Charles Kisseberth (eds.), Theoretical Aspects of Bantu Tonology, CSLI, Stanford. Pp. 265-314.

Peterson, Karen. 1989. "A comparative look at Nguni verbal tone." In Isabelle Haik and Lauice Tuller (eds.), Current Approaches to African Linguistics, vol. 6, Foris: Dordrecht. Pp. 115-137.

Poletto, Robert. 1998. "Topics in Runyankore phonology." Doctoral dissertation, Ohio State University.

Pulleyblank, Douglas. 1983. "Accent in Kimatuumbi." In Jonathan Kaye et al. (eds.), Current Approaches to African Linguistics, vol. 2, Foris: Dordrecht. Pp. 195-215.

Richardson, Irvine. 1959. The Role of Tone in the Structure of Sukuma. SOAS: University of London.

Roberts, R. Ruth 1992. "A non-metrical theory of Sukuma tone." In Elizabeth Hume (ed.), Papers in Phonology, OSU Working Papers in Linguistics 41: 135-148. 
Schadeberg, Thilo and Clement Maganga. 1992. Kinyamwezi: Grammar, Texts, Vocabulary. Rüdiger Köppe: Köln.

Schadeberg, Thilo. 1991. "High Tone Shift in KiNyamwezi." In Kathleen Hubbard (ed.), Proceedings of the Seventeenth Annual Meeting of the Berkeley Linguistics Society: Special session on African Language Structures, BLS: Berkeley. Pp. 210-221.

Yukawa, Yasutoshi. 1989. "A tonological study of Sukuma verbs." In Studies in Tanzanian Languages, Bantu linguistics 2. Tokyo: Institute for the Study of Languages and Cultures of Asia and Africa. Pp. 339-404

Department of Linguistics

Ohio State University

Columbus, $\mathrm{OH} 43210$

e-mail: odden@ling.ohio-state.edu
[Received October 2001; accepted March 2002] 
Studies in African Linguistics

Volume 30, Number 1, Fall 2001

Notes and Queries 
